\section{Belet Lydia Ingrit ${ }^{1}$}

'Universitas Pelita Harapan

Corresponding Author: Belet Lydia Ingrit

Email: lydia_inggrid@yahoo.com

\title{
The Application of Levine's and Kolcaba's Theories in the Nursing Care of Patients with the Third Stadium of Cervical Cancer
}

$\begin{array}{ll}\text { Article Info } & \\ \text { Online } & : \text { http://journal.umy.ac.id/index.php/ijnp } \\ \text { ISSN } & : 25484249 \text { (Print) } \\ & : 2548 \text { 592X (Online) } \\ \text { DOI } & : 10.18196 / \text { ijnp.3296 }\end{array}$

Abstract
Background: Cervical cancer was the second leading cause of cancer
in Indonesia. New cases of cervical cancer are found in Indonesia each
year.

Objective: This study aims to describe an application of Levine's Conservation Nursing Theory and Kolcaba's Comfort Theory in a patient with the third stadium of cervical cancer.

Method: The method used in this study was a narrative of a case report in one patient with the third stadium of cervical cancer at the hospital in Central Jakarta. She is 44 years old, who has been diagnosed since October 2017. She experienced nausea and vomiting a week before she was hospitalized and had a history of vaginal discharge ever since nine months ago. Levine's conservation interventions were provided to maintain energy, improve adaptability, improve standard comfort, educate, and provide comfort.

Results: The result showed that the patient was able to adapt to the condition of the illness and obtained a sense of comfort during hospitalization. Therefore, Levin's conservation theory and Kolcaba's comfort theory can be applied in performing nursing care in patients with cervical cancer.

Conclusion: The three stages of Kolkaba's comfort intervention can improve patient comfort not only physically but also psychologically during treatment.

Keywords: Cervical cancer, Kolcaba's comfort, Levine's conservation, Nursing care

\section{INTRODUCTION}

The prevalence of cancer incidence in the world still has the highest rank after cardiovascular disease and becomes the leading cause of death. The total number of patients of cancer today in the world is 32.4 million and $52 \%$ of them are suffered by many women (International agency for cancer research, 2014). In Southeast Asia, the incidence of cervical cancer accounts for $20-30 \%$ of all cancers (Bal, Goyal, Suri \& Mohi, 2012). According to the data revealed by the Ministry of Health of the Republic of Indonesia (2015), in 2013, cervical cancer was the highest prevalence in Indonesia by $0.8 \%(98,692$ cases). Twenty-one thousand new cases of cervical cancer are found in Indonesia each year and continue to increase (Afiyanti \& Pratiwi, 2017).

Cervical cancer is one of the diseases that currently becomes a health concern throughout the world, especially in developing countries. The cancer is a malignancy from the cervix that is caused by infection with the Human Papilloma Virus (HPV). Approximately $70 \%$ of cervical cancer cases worldwide are caused by HPV types 16 and 18 .

In general, precancerous lesions have not shown symptoms. However, when it becomes invasive cancer, the most common symptoms are bleeding during sexual intercourse, unstoppable bleeding, and excessive vaginal discharge. The risk factors for cervical cancer are sexual activity at a young age, sexual intercourse with multiple partners, smoking, multiple children, low socioeconomics, use of birth control pills, sexually transmitted diseases, and immune disorders (National Committee of Cancer Management, 2014). 


\section{NUNRSING \\ PRACTICES}

Cervical cancer can cause problems such as morbidity, suffering, death, and financial problems for the family. Therefore, it is important to conduct early prevention for women in cervical cancer.

Nurses, as part of the health workers, have a role in providing comprehensive nursing care to patients with cervical cancer. This case study report aims to describe the result of nursing care to the patient with cervical cancer using Levin's conservation theory and Kolcaba's comfort theory. In this case, the patient examined was in the third stadium of cervical cancer. Levin focuses on improving the adaptability to environmental change and maintaining the integrity of individuals either physically, personally, or socially by using conservation principles. Meanwhile, the need for comfortable feeling is viewed from the context of a holistic comfort, which consists of four aspects, namely physical, psychospiritual, environment and social, with three levels of comfort namely relief, ease, and transcendence (Tomey \& Alligood, 2006).

The first steps in nursing assessment with Levin's conservation theory are an observation of pain response, viewing medical reports on patient status, and a diagnostic examination result to find out patient's needs. The assessment also includes assessing internal and external environmental changes that encompass four conservation principles namely energy conservation, structural integrity, personal integrity, and social integrity (Alligood, 2014).

The second step is to formulate tropicognosis. Tropicognosis is a nurse decision based on the consideration of factors affecting the health condition of cervical cancer patients. The third stage is to make a hypothesis, often referred to as a nursing diagnosis. The fourth stage is intervention and then evaluation. The whole attainment is that patient is able to adapt to changes that occur to the four principles of Levin's conservation.

Assessment of the four comfort aspects includes physical, psychospiritual, environmental, and social contexts. Each context is categorized into the level of comfort, which encompasses relief defined as a state in which comfort is reduced, ease defined as the loss of specific discomfort, and transcendence defined as reinforcing and reminding nurses not to give up in helping patients and their families to improve their comfort. The context of comfort as a holistic experience is considered based on four aspects, such as physical, psychospiritual, environmental and social (Tomey \& Alligood, 2006).

\section{METHOD}

The method used in this article was a narrative of a case report in one patient who suffers from the third stadium of cervical cancer in the inpatient ward at the hospital in Central Jakarta. The investigation was carried out by using the nursing care approach adopting Levin's nursing theory of conservation and Kolcaba's comfort theory from the assessment stage until the evaluation stage. The subject investigated is, Mrs. ESH (44 years), P2A0, medically diagnosed with the third stadium of cervical cancer since October 2017 with a bilateral post of nephrostomy admitted from the hospital since 02 November 2017. Mrs. ESH is a Sundanese and Muslim housewife with two children, who has married once for 15 years. Her last formal education background is elementary school. The history of contraceptive use is a three-month contraceptive for 17 years and pills for four years. The obstetric history of menarche is 15 years, and the menstrual cycle is regular and does not feel pain during the menstruation. The patient said that she still had menstruation periods and she never had an IVA test.

The frequent symptoms that the patient felt were nausea and vomiting one week before being hospitalized. Another complaint was vaginal discharge since nine months ago although there was no bleeding. However, every time she had sexual intercourse, she got bleeding. The patient had also lost weight during the last two months as much as 7 $\mathrm{kg}$. Nausea and vomiting were felt the last week before she got hospitalized. The loss of appetite and bowel complaints were not found as a problem but the urination issue was a problem as the patient urinated just a little over two days before being hospitalized.

The patient used bilateral nephrostomy to help urinating because she had difficulty in it. The use of nephrostomy caused pain to the patient that she felt pain from the abdomen spreading until the waist. She said that the pain scale was 10 out of 10 , so it is categorized as a heavy pain to her. The pain made 
the patient have no passion and was unable to perform activities independently. The patient seemed to be uncommunicative, moody and she stated that the illness was a test from God. The results of vital observation signs obtained blood pressure $117 / 80 \mathrm{mmHg}$, pulse 76 times per minute, breathing 18 times per minute, temperature $360 \mathrm{C}$, and 99 percent oxygen saturation.

Assessment for conservation energy was carried out by collecting the data from the subjective and objective aspects. Subjective data is an assessment result from complaints or patient's perceptions of her health status (Dinarti \& Mulyanti, 2017). In this case, the patient said that she had no appetite and felt frequent nausea. It was observed from the portion of her leftover food. Since she had been sick, she revealed that she had lost weight from $55 \mathrm{~kg}$ to $48 \mathrm{~kg}$, and based on the observation, the patient looked thinner. According to the laboratory test, the result showed that the patients' hemoglobin was below the normal value that was $7 \mathrm{gr} / \mathrm{dl}$. That was one of the reasons why the patient looked pale. Furthermore, based on ECOG performance status, the patient was in the third grade. She had limited movement and self-care ability, confined to bed or chair more than $50 \%$ of her waking hours (ECOGACRIN, 2018).

The Integrity structural conservation assessment showed that the patient looked pale and the conjunctiva looked anemic. Besides that, the patient also looked jaundice in the sclera area, dry lips, cyanotic, Capillary Refill Time more than 3 seconds, extremities in cold feeling, and skin turgor elastic. There was no edema and no enlargement either in the neck or in the axilla. The patient had bilateral post-nephrostomy procedures before medical diagnose such as AKI (Acute Kidney Injury). AKI became the previous complaint where the patient had difficulties in urine issues.

The result of the assessment on the conservation of personal integrity shows that the patient surrendered for her disease. The patient also hoped that the treatment conducted could provide healing. Meanwhile, the result of the conservation assessment on social integrity shows that the patient tended to be calm, was able to work together with any action provided by the health team. However, the patient is more likely to be moody and rarely communicated with others in her room.

On the other hand, there are four parts of the comfort measurement standard according to Kolcaba assessment. There is physical comfort which includes psychological and behavioral and emotional comfort which includes sociocultural, spiritual, and environmental comforts. Data objective from physical and physiological assessment aspects showed that the patient complained about discomfort such as pain in the surgery location (procedure of nephrostomy), and also her nausea and the absence of appetite so that she had lost weight during the illness.

Based on the psychospiritual aspect, the patient stated that the illness was the experience for her life, and a test from God so that she could only surrender, accept, and try to recover her health. Nurses and other health workers provided mental support such as listening to patient complaints, providing positive advice, empathy, and information support such as explaining nursing or medical procedure, and also providing health education.

The social factor of the nearest person is very meaningful for the patient, especially the patient's mother who waited for the patient every day in the hospital and helped the patient's activity. There is no cultural prohibition for a patient undergoing treatment at the hospital. Support from health workers and family and spiritual aspects by facilitating the patient to pray, helped to make decision making and giving a caring attitude toward the patient. Based on the environmental comfort assessment, the patient was in a fully furnished room with six-bed capacity, one air conditioner, one ventilated door, and the patient's position were located near the windows.

\section{RESULTS}

Nursing diagnosis according to Levin and Kolkaba's assessment theory to this patient were: 1) Conservation disorders of structural integrity such as tissue perfusion associated with a decrease in oxygen supply, 2) Discomfort such as pain related to nephrostomy wound surgical incision, 3) Less nutrition for body's needs due to inadequate intake, 4) Conservation disorder of structural integrity such as a change of elimination pattern associated with infiltration of cancer in urinary tract, 5) Anxiety 


\section{NURSSING \\ PRACTICES}

associated with a lack of knowledge about disease and treatment procedures.

Upon finding the nursing diagnosis, the next step was to make several goals from each diagnosis. They are as follow:

1) Conservation disorders of structural integrity, such as tissue perfusion resolved with the result of the criteria. The criteria were vital signs within normal limits that the patient does not look weak, Capillary Refill Time was less than 3 seconds, and extremities felt warm and no visible cyanosis. Interventions of structural integrity conservation disorders of tissue perfusion were by observing vital signs, especially blood pressure and pulse, observing the Capillary Refill Time and nail bed color, observing circulation status, encouraging patients for bed rest and collaboration in transfusion therapy, laboratory examination (hemoglobin), and oxygen therapy if necessary.

2) The patient's pain decreased with the result criteria of vital signs within normal limits. The patient revealed that the pain was controlled, decreased and that she looked calm and could perform a relaxation technique and distraction appropriately as an indication of a pain-control. The nursing intervention was to examine the history of pain, the area of the pain, frequency, duration, intensity, and scale, by giving necessary comfort measures such as relaxation, distraction, imagination or soft massage, observing and monitoring vital signs, providing a comfortable position and doing a collaboration in giving analgetic medicine.

3) The patient's nutritional status could be maintained with several criteria to meet the needs of the body. The outcomes of the criteria were patients were able to consume portions of food, there was no conjunctiva anemic, the weight was normal, and hemoglobin values were within normal limits. Interventions for energy conservation disorders were such as fewer nutrients than the body's needs assessed the nutritional status of the patients, measuring weight as indicated, motivating patients to eat high-calorie and high-protein foods, monitoring daily food input, and encouraging patients to eat small portions but often.
4. The diagnosis of nursing for Conservation disorder of structural integrity included a change of elimination pattern. The aim was that the elimination pattern returns to normal (adequately) with expected outcome criteria. The outcome criteria were incontinence urine resolved. Interventions for conservation of structural integration are such as changes in the pattern of elimination which observed urine output, observed the urine color and the presence of an abnormal odor, provided fluid enhancement and fluid intake, observed the vital signs, peripheral pulse, capillary refill time, and did collaboration in the examination laboratory (urea and creatinine).

5. Nursing diagnosis with the patient's anxiety could be reduced with the patient's outcome criteria. The outcome criteria were patient stated that anxiety diminishes or disappears. Furthermore, other criteria are safety, and a comfortable environment for the patient and that patient looks relaxed. In addition, the patient gets accurate information and support from the nearest relative, like husband and other family members. Interventions for discomfort problems include anxiety are such as motivating the patient to express her thoughts and her feelings, providing an open environment, maintaining effective communication by caring for the patient, and helping the patient or the nearest person in recognizing and clarifying fear.

A communicative therapist must conduct five nursing diagnoses with several interventions for each diagnosis and that it can heal the patient and accept her condition with the illness.

Upon conducting the intervention, the next step for the nurse is to make an evaluation. Evaluation is carried out every day after implementation. It is conducted by asking the patient's complaints (subjective data) and evaluation with observation and secondary data from laboratory results or medical records (objective data). In terms of this case, the evaluation from each diagnosis is that the five nursing problems are partially resolved so that further interventions are needed to improve the patient's condition.

\section{DISCUSSIONS}

Cervical cancer is a malignancy from the cervix caused by infection with Human Papillomavirus 
(National Committee of Cancer Management, 2014). National Committee of Cancer Management (2014) also stated that HPV types 16 and 18 are the leading causes in $70 \%$ of cases of cervical cancer in the world.

National Committee of Cancer Management (2014), also reveals that the risk factors for cervical cancer are sexual activity at a young age, sexual intercourse with multiple partners, smoking, multiple children, low socioeconomic, use of birth control pills, sexually transmitted diseases, and immune disorders. It indicates that there are several risk factors for cervical cancer. It is in line with the research conducted by Hidayat, Hasibuan \& Fitriyati (2013), stating that the number of parity influenced the incidence of cervical cancer.

In this case, Mrs.ESH (44 years old) is a woman and a housewife. Nursing care did to her includes many aspects, from assessment to evaluation. Then, Levin's conservation theory and Kolkaba's comfort theory start with an assessment of subjective or objective data collection. The subjective and objective data results are the basis for the interventions. Implementation is given under the planning or intervention. Evaluation is obtained based on the result from subjective and objective data of the patient after implementation is given.

Interventions are given under Levin's conservation principles and Kolkaba's comfort in five nursing issues experienced by patients during hospitality. Structural integrity conservation disorders are such as tissue perfusion resolved by nursing independent interventions. In this case, it is conducted by monitoring vital signs, checking Capillary Refill Time, nailing bed colors, and observing patient circulation status. Therefore, it can conserve tissue structures that can help adequate tissue perfusion. Meanwhile, the nursing collaboration intervention is conducted by giving the therapy of transfusion PRC. Post-transfusion hemoglobin in patients increases after the PRC of $500 \mathrm{cc}$.

It is relevant to the final report from Fitriani, Setyowati \& Afiyanti (2016), who said that Levine's conservation theory could be applied to cervical cancer patients with bleeding. Nursing care for supporting perfusion encourages the patient to take a rest. The purpose is to reduce oxygen needs, so the oxygen in the body can be prioritized to important organs.

The next nursing problem is a sense of comfort. The evaluation found was that patients said the pain had been reduced, but the problem for nausea and appetite complaints still existed even though the portion of food eaten had increased. In terms of the problem of the elimination pattern, the patient has been assisted by using nephrostomy, but the nurse's independent actions are still required in monitoring urine output /production, fluid balance, urine color, and turbidity. National Cancer Management Committee (2014) stated that treatment for cervical cancer in the third stadium with CKD (Chronic Kidney Disease) is with nephrostomy or (if needed) with hemodialysis while other treatments are chemoradiation and radiation.

Not only physic, but psychology also becomes the problem of the patient. It is proved by the result showing that the patient experienced the nursing problem of anxiety. It is supported by qualitative research conducted by Yolanda and Karwur (2013), revealing that $60 \%$ of patients with cervical cancer have a level of anxiety. In this case, the anxiety has been reduced by the independent actions of nurses in giving information. The information is related to nursing caring during the patient's hospitality.

In relation to this, the profile of the patient, in this case, is a 44-year older woman with a 15-year marriage history. It is a risk factor for patients with cervical cancer. Besides the history of marriage at a young age, being at the age of over 35 years old also has a risk factor for the occurrence of cervical cancer (Diananda, 2007). It is supported by the research conducted by Herlana, Nur, \& Purbaningsih (2017), stating that the highest frequency of cervical cancer is at the age of more than 35 years old with parity of more than three children.

Cervical cancer can be effectively prevented by HPV vaccination, but this is influenced by family support and patients' knowledge levels. According to a study by Sari \& Syahrul (2014), the knowledge levels affect a person to take HPV vaccination in adult women. In this case, Mrs.ESH only graduated from elementary school, and she never took an IVA test. Besides that, the history of contraceptive use is also a risk factor for cervical cancer. In the case of Mrs. ESH, she had a history of injecting contraceptive use for 17 years 


\section{NURSTING \\ PRACTICES}

and birth control pills for four years. It indicates that contraceptive use is the leading risk factor for cervical cancer.

Furthermore, Mrs. ESH (47 years) also had a vaginal discharge history for nine months. It smelt and flowed like water. The disease process made her body had weight loss. The patient had drastic weight loss during the last two months of $7 \mathrm{~kg}$. The patient also feels the experience of related pain.

On the other hand, anemia also becomes a significant problem in cervical cancer. The patient came to the hospital with a history of anemia. Hemoglobin on the first day in the hospital was below a normal value that was less than $12 \mathrm{~g} / \mathrm{dl}$. The patient was diagnosed with the status of anemia because the hemoglobin is just $7 \mathrm{gr} / \mathrm{dl}$. Upon being given 500cc transfusion, the hemoglobin level raised until $12 \mathrm{gr} / \mathrm{dl}$. Therefore, the nurses can apply Levin's Conservation theory to resolve the tissue perfusion problem caused by bleeding or anemia with a hemoglobin level below normal values. A collaboration with other health services by giving a Packed Red Cell transfusion can help improve the patient's health status. In addition, the independent intervention from nurses in helping the patient's daily activities can conserve the energy of the patient.

Another nursing problem that can be solved by using Levin's conservation theory is a disorder of nutrition fulfillment. It is a condition when the nutrition portion is less than the body requirements associated with inadequate intake characterized by nausea and anorexia. In addition, Kolkaba's comfort theory can be used to solve nursing diagnoses for discomforts such as pain related to nephrostomy wound surgical incision and tissue necrosis of the cervix due to cervical cancer. There are no bowel complaints, but there is a problem in secrete urine. The patient just had anuria over two days before being hospitalized. Therefore, Levin's conservation nursing theory, especially on the principle of conservation of structural integrity and energy conservation, is needed in this nursing problem. The intervention given directly to the patient is to achieve the wholistic care and improve adaptation. Levin's hypothesis is a nursing intervention provided by the direct care provider because the nurse directly provides nursing care independently or collaboratively with other health teams such as the nutrition and medical team. Wuriningsih (2016) stated that the application of Levin's conservation nursing theory could help maternity nurses to be able to do holistic, active, and independent awareness of caring in patients with cervical cancer.

In this case, the patient with the third stadium of cervical cancer feels discomfort not only physically but also psychospiritual, environmental, and social. Physical discomfort is caused by the presence of cervical cancer itself with the suppression of cancer cells in the tissues of nerve cells that cause the patient to feel pain. In addition, the installation of catheters and nephrostomy also makes discomfort in the patient. Other discomforts may also be due to bleeding or vaginal discharge, discomfort in the case of urination, discomfort with a crowded environment, or discomfort with the surrounding environment.

Psychospiritual discomfort is also felt because the cervical cancer process makes patients anxious from the treatment process and despair in undergoing the disease. Meanwhile, environmental discomfort is influenced by the atmosphere of a treatment room that is not supportive of being able to get rest well. Convenience or comfort feeling is a holistic phenomenon and is a basic need of every human. Therefore, nursing interventions are needed to solve the discomfort and improve comfort in patients.

There are three steps in Kolkaba's comfort intervention. The first step is standard comfort, such as maintaining hemostasis and pain control; the second step is by coaching (coaching and training). Coaching is giving education to patients to relieve her anxiety, provide information, listen, and help plan recovery, and the last one is the third step that is a comfort for the soul as a soul-soothing act, such as massage or guided imagery. Besides that, support from the couple (husband) is also a comfort for the patient so that the anxiety can be reduced.

Furthermore, health education about the disease and its treatment can help to reduce patient's anxiety due to lack of information and her disease. Massage and guided imagery can help the patient 
reduce her pain. A soothing touch can provide comfort for cervical cancer patients. This massage action is a nurse's independent intervention as a part of collaborative intervention with analgesic granting such as duragesic patch.

\section{CONCLUSIONS}

Patients with the third stadium of cervical cancer are advanced-stage cancer patients who require comprehensive maternity care both physically and psychologically. Therefore, the application of Levin's Conservation model and Kolkaba's comfort theory is necessary. The nursing theory uses four principles of Levin's conservation and Kolkaba's comfort model to provide support for patient adaptation in the healing process. By conserving structural integrity and energy conservation, patients can solve the problems. Furthermore, the three stages of Kolkaba's comfort intervention can improve patient comfort not only physically but also psychologically during treatment.

\section{REFERENCES}

Afiyati, Y \& Pratiwi, A. (2017). Seksualitas dan kesehatan reproduksi perempuan: Promosi, permasalahan dan penanganannya dalam pelayanan kesehatan dan keperawatan. Edisi 1.Cetakan 2. Jakarta: Rajawali Press.

Alligood, M.R., (2014). Nursing theory: Utilization \& application. 4th edition. Philadelphia: Mosby

Bal, M.S., Goyal, R., Suri, A.K., \& Mohi, M.K. (2012). Detection of abnormal cervical cytology in Papanicolaou smears. J Cytol, 29 (1), 45-47.

Diananda, R. (2007). Mengenal Seluk Beluk Kanker. Yogyakarta: Katahati

Dinarti \& Yuli Mulyanti. (2017). Dokumentasi Keperawatan. Jakarta: BPPSDMK Ministry of Health of the Republic of Indonesia. Retrieved from

http://bppsdmk.kemkes.go.id/pusdiksdmk/ wp-

content/uploads/2017/11/PRAKTIKADOKU MEN-KEPERAWATAN-DAFIS.pd

ECOG-ACRIN. (2018). ECOG Performance Status. Retrieved from https://ecogacrin.org/resources/ecog-performancestatus

Fitriani, H., Setyowati \& Afiyanti, Y. (2016). Kegiatan Residensi Spesialis Keperawatan maternitas Fokus Penerapan" Need for Help Wiedenbach" dan "Conservation Levine" pada Asuhan Keperawatan pada Pasien Perdarahan karena Kanker Serviks. Jurnal Skolastik Keperawatan, 2 (1), 59-69

Herlana, F., Nur, I. M., \& Purbaningsih, W. (2017). Karakteristik Pasien Kanker Serviks berdasar atas Usia, Paritas, dan Gambaran Histopatologi di RSUD Al-Ihsan Bandung. In Bandung Meeting on Global Medicine \& Health (BaMGMH). 1(1), 138-142.

Hidayat, E., Sari, D. H., \& Fitriyati, Y. (2014). Hubungan Kejadian Kanker Serviks Dengan Jumlah Paritas Di RSUD Dr. Moewardi Tahun 2013. Jurnal Kedokteran dan Kesehatan Indonesia, 6(3), 128-136.

International agency for cancer research. (2014). Cancer prevention. Swiss: WHO Press

Ministry of Health of Republic Indonesia. (2015). Infodatin: Pusat data dan informasi kementerian Kesehatan RI tentang informasi penyakit kanker. Jakarta: Kemenkes Republik Indonesia

National Committee of Cancer Management. (2014). Panduan Penatalaksanaan Kanker Serviks. Retrieved from kanker.kemkes.go.id/guidelines/PPKServiks. $p d f$

Sari \& Sahrul. (2014). Faktor yang berhubungan dengan tindakan vaksinasi HPV pada wanita usia dewasa. Jurnal Berkala Epidemiologi, 2(3), 321-330.

Tomey \& Alligood. (2006). Nursing theorist and their work. 6th Edition. St. Louis: Mosby Elsevier, Inc

Wuriningsih, A.Y. (2016). Potret asuhan keperawatan maternitas pada klien dengan kanker serviks melalui pendekatan konservasi dan efikasi diri. Nurscope, Jurnal Keperawatan dan Pemikiran IImiah, 2(6), 111.

Yolanda, A.E., \& Karwur, F.F. (2013). Tingkat Kecemasan Pasien Kanker Serviks pada Golongan Ekonomi Rendah yang Mengikuti Program Kemoterapi di RSUD Dr. Moewardi. Sains Medika, 5 (2), 68-81. 